\title{
Antistaphylococcal and Antibiotic Resistance Modulatory Activities of Thirteen Cameroonian Edible Plants against Resistant Phenotypes
}

\author{
Brice E. N. Wamba, Armelle T. Mbaveng $(\mathbb{D}$, Paul Nayim, Joachim K. Dzotam, \\ Ornella J. T. Ngalani, and Victor Kuete $\mathbb{D}$
}

Department of Biochemistry, Faculty of Science, University of Dschang, Dschang, Cameroon

Correspondence should be addressed to Victor Kuete; kuetevictor@yahoo.fr

Received 24 March 2018; Accepted 6 June 2018; Published 3 July 2018

Academic Editor: Clemencia Chaves-López

Copyright (c) 2018 Brice E. N. Wamba et al. This is an open access article distributed under the Creative Commons Attribution License, which permits unrestricted use, distribution, and reproduction in any medium, provided the original work is properly cited.

\begin{abstract}
Background. In this study, 18 methanol extracts from Cameroonian edible plants were tested for their antibacterial activities against 26 strains of $S$. aureus; the role of efflux pumps in the resistance of tested bacteria and the antibiotic resistance-modulating activities against selected multidrug-resistant (MDR) phenotypes were also investigated. Methods. Broth microdilution assay was used to evaluate the antibacterial activity, the role of efflux pumps, and the antibiotic resistance-modulating effects of plant extracts. Results. Extracts from Dacryodes edulis seeds (DES) and Dacryodes edulis bark (DEB) were active against all 26 tested bacterial strains, within the minimal inhibitory concentration (MIC) range of 256-1024 $\mu \mathrm{g} / \mathrm{mL}$. MIC values varied from 64 to $1024 \mu \mathrm{g} / \mathrm{mL}$ against $96.2 \%$ of the 26 tested bacteria for Phaseolus vulgaris leaves (PVL), 92.3\% for Azadirachta indica bark (AIB), Dacryodes edulis leaves (DEL), and Ricinodendron heudelotii leaves (RHL). The lowest MIC value of $64 \mu \mathrm{g} / \mathrm{mL}$ was obtained with the extract from Cucurbita maxima beans (CMB) against MRSA4 strain and from Uapaca guineensis bark (UGB) against MRSA9 strain. Bacterial efflux pump inhibitor (EPI), carbonyl cyanide $m$-chlorophenyl hydrazone (CCCP), improved the activity of DES and UGB as well as that of extracts from Hibiscus esculentus leaves (HEL) and Uapaca guineensis leaves (UGL) against resistant S. aureus strains. Antibiotic-modulating effects against more than $70 \%$ of the $S$. aureus strains tested were obtained when RHL (at MIC/2) was combined with CIP, ERY, and KAN (88.89\%), CHL (88.89\%), TET (77.78\%), and STR (88.89\%). Conclusion. The present study demonstrated that the 13 tested plants had antistaphylococcal effects and that DES, HEL, UGL, and UGB could be used in combination with EPI to combat resistance to Staphylococcus aureus. Also, it demonstrated that some studied extracts and mostly RHL could be used as antibiotic resistance modulators to fight against resistant strains of S. aureus.
\end{abstract}

\section{Background}

Bacterial infections caused by Staphylococcus aureus are globally responsible for $7-10 \%$ of deaths annually [1]. It is the most virulent species of the genus Staphylococcus and has emerged as one of the most important human pathogens in the last decades, being one of the main causes of hospital and community infections [2]. This bacterium causes a wide range of clinical infections, ranging from common infections such as skin and soft tissue infections to septicemia, pneumonia, and toxinosis $[3,4]$. The fight against $S$. aureus is hindered by the development of resistance of various strains to antibiotics [5-9]. The multidrug resistance (MDR) observed in Gram-positive bacteria is mostly attributed to overexpression of efflux pumps and antibiotics-degrading enzymes. This MDR of $S$. aureus propels the search of new antibacterials with more efficiency and low toxicity. Plant kingdom contains a variety of pharmacologically active 
secondary metabolites, and some of them have been reported for their antibacterial activities $[10,11]$. Their use to combat $S$. aureus antibiotic resistance is an attractive strategy. In regard to the loss of efficacy of several antibiotics and the scarcity of new antibacterial agents, it is also important to search for substances capable of restoring the activity of antibiotics. Antibacterial screenings of African plants have yielded promising results in the past [12-15]. The present study was set up to evaluate the antistaphylococcal potential of 13 Cameroonian food plants: Azadirachta indica A. Juss (Meliaceae), Citrus grandis (L.) Osbeck (Rutaceae), Cucurbita maxima Duch. (Cucurbitaceae), Dacryodes edulis (G. Don) H. J. Lam (Burseraceae), Hibiscus esculentus L. (Malvaceae), Ipomoea batatas (L.) Lam (Convolvulaceae), Irvingia gabonensis (Aubry. Lec. ex O. Rorke) Baill. (Irvingiaceae), Phaseolus vulgaris L. (Fabaceae), Ricinodendron heudelotii (Baill.) Pierre ex Heckel (Euphorbiaceae), Saccharum officinarum L. (Poaceae), Spondias mombin L. (Anacardiaceae), Theobroma cacao L. (Sterculiaceae), and Uapaca guineensis Muell. Arg. (Euphorbiaceae). The study was extended on the role of efflux pumps in resistance to some plant extracts as well as the ability of extracts to potentiate the activity of selected antibiotics.

\section{Materials and Methods}

2.1. Plant Materials and Extraction. The thirteen edible plants were collected from different localities of Cameroon, namely, Obala (Centre Region), Muyuka (SouthWest Region), and Dschang (West Region) from March to April 2016. The collected plant samples included the bark of Azadirachta indica A. Juss (Meliaceae), leaves of Citrus grandis (L.) Osbeck (Rutaceae), beans of Cucurbita maxima Duch. (Cucurbitaceae), leaves, bark, and seeds of Dacryodes edulis (G. Don) H. J. Lam (Burseraceae), leaves of Hibiscus esculentus L. (Malvaceae), beans of Ipomoea batatas (L.) Lam (Convolvulaceae), leaves of Irvingia gabonensis (Aubry. Lec. ex O. Rorke) Baill. (Irvingiaceae), leaves of Phaseolus vulgaris L. (Fabaceae), bark and leaves of Ricinodendron heudelotii (Baill.) Pierre ex Heckel (Euphorbiaceae), leaves of Saccharum officinarum L. (Poaceae), leaves of Spondias mombin L. (Anacardiaceae), leaves and beans of Theobroma cacao L. (Sterculiaceae), and leaves and bark of Uapaca guineensis Muell. Arg. (Euphorbiaceae). Plants were identified at the National Herbarium in Yaoundé (Cameroon) where the voucher specimens were conserved under the registration numbers (Table 1). The dried and powdered material $(100 \mathrm{~g})$ of each plant was macerated in $300 \mathrm{~mL}$ of methanol at room temperature for $48 \mathrm{~h}$ and then filtered using Whatman filter paper No. 1. The filtrate obtained was concentrated using a rotary evaporator under reduced pressure to obtain the crude methanol extract, which was kept at $4^{\circ} \mathrm{C}$ until further use.

2.2. Chemicals. Eight reference antibiotics (RA) purchased from Sigma-Aldrich (St Quentin Fallavier, France) were tested: ampicillin (AMP), cefepime (CEF), chloramphenicol
(CHL), ciprofloxacin (CIP), erythromycin (ERY), kanamycin (KAN), streptomycin (STR), and tetracycline (TET); $p$-iodonitrotetrazolium chloride (INT) (Sigma-Aldrich) was used as bacterial growth revelator; carbonyl cyanide $m$ chlorophenyl hydrazone (CCCP) and chlorpromazine (CPZ) (Sigma-Aldrich) were used as efflux pump inhibitors (EPIs); and dimethylsulfoxide (DMSO) was used to dissolve the plant extracts.

2.3. Bacteria, Culture Media, and Growth Conditions. The strains of Staphylococcus aureus used included a reference strain obtained from American Type Culture Collection (ATCC; ATCC 25923), 8 methicillin-resistant S. aureus (MRSA) strains (MSSA1, MRSA3, MRSA4, MRSA6, MRSA8, MRSA9, MRSA11, and MRSA12) (obtained from the culture collection of the Laboratory of Microbiology, Graduate School of Pharmaceutical Sciences, The University of Tokyo, Japan, and provided by Dr Jean P. Dzoyem, University of Dschang) [8,9], and 17 resistant clinical laboratory strains of $S$. aureus (SA01, SA07, SA18, SA23, SA36, SA39, SA56, SA64, SA68, SA88, SA114, SA116, SA124, SA126, SA127, SA135, and SA139) available in our laboratory collection and previously isolated from patients in Ad-Lucem Hospital in Banka-Bafang (West Region of Cameroon) [54]. Their bacterial features are summarized in Table 2. They were cultured at $37^{\circ} \mathrm{C}$ overnight on Mueller Hinton agar $24 \mathrm{~h}$ prior to any assay. The Mueller Hinton broth (MHB) was used as liquid culture medium for susceptibility tests.

2.4. Preliminary Phytochemical Screenings. Potential classes of potential antibacterial phytochemicals such as alkaloids (Dragendorff's and Mayer's tests: $5 \mathrm{mg}$ plant extract in $10 \mathrm{~mL}$ methanol; a portion of $2 \mathrm{~mL}$ extract $+1 \% \mathrm{HCl}+$ steam, $1 \mathrm{~mL}$ filtrate +6 drops of Mayor's reagents/Wagner's reagent/Dragendorff's reagent; cream precipitate/brownish-red precipitate/orange precipitate indicated the presence of respective alkaloids), saponins (frothing test: $0.5 \mathrm{~mL}$ filtrate $+5 \mathrm{~mL}$ distilled water; frothing persistence indicated the presence of saponins), steroids and triterpenoids (Liebermann-Burchard test: $5 \mathrm{mg}$ plant extract in $10 \mathrm{~mL}$ chloroform, filtered; a $2 \mathrm{~mL}$ filtrate $+2 \mathrm{~mL}$ acetic anhydride + conc. $\mathrm{H}_{2} \mathrm{SO}_{4}$; blue-green ring or pink-purple indicated the presence of steroids or triterpenoids), phenolics: anthraquinones ( $5 \mathrm{mg}$ plant extract in $10 \mathrm{~mL}$ methanol; a portion of $2 \mathrm{~mL}+2 \mathrm{~mL}$ ether-chloroform $1: 1 \mathrm{v} / \mathrm{v}+4 \mathrm{~mL} \mathrm{NaOH} 10 \%$ $(\mathrm{w} / \mathrm{v})$; red color indicated the presence of anthraquinones), flavonoids ( $5 \mathrm{mg}$ plant extract in $10 \mathrm{~mL}$ methanol; a portion of $2 \mathrm{~mL}+$ conc. $\mathrm{HCl}+$ magnesium; ribbon pink-tomato red color indicated the presence of flavonoids), polyphenols (ferric chloride test: $5 \mathrm{mg}$ plant material in $10 \mathrm{~mL}$ methanol; a portion of $2 \mathrm{~mL}+2 \mathrm{~mL} \mathrm{FeCl}_{3}$; violet-blue or greenish color indicated the presence of phenols), and tannins ( $5 \mathrm{mg}$ plant extract in $10 \mathrm{~mL}$ distilled water; a portion of $2 \mathrm{~mL}+2 \mathrm{~mL}$ $\mathrm{FeCl}_{3}$; blue-black precipitate indicated the presence of tannins) (Table 3) were investigated according to the described phytochemical methods $[11,55]$. 
TABLE 1: Information on the studied plants.

\begin{tabular}{lccc}
\hline $\begin{array}{l}\text { Species (family); voucher } \\
\text { number }\end{array}$ & Traditional uses & $\begin{array}{c}\text { Bioactive or potentially bioactive } \\
\text { components }\end{array}$ & $\begin{array}{c}\text { Known antimicrobial activities of } \\
\text { plants }\end{array}$ \\
\hline $\begin{array}{l}\text { Azadirachta indica A. Juss } \\
\text { (Meliaceae); 4447/SRFK }\end{array}$ & $\begin{array}{c}\text { Antimalarial, anticancer, anti- } \\
\text { inflammatory, antidiabetic, } \\
\text { antihyperglycaemic, antiulcerous }\end{array}$ & $\begin{array}{c}\text { Antibacterial activity of ethanol } \\
\text { leaf extract: } E c, K p, P m, S a, P a, E f\end{array}$ \\
{$[16]$} & $\begin{array}{c}\text { Alkaloids, glycosides, flavonoids, ethanol and methanol } \\
\text { and saponins [17] }\end{array}$ & $\begin{array}{c}{[18]} \\
\text { extract of leaves: } E c, P a, S t, S a, B p\end{array}$
\end{tabular}

[16]

\begin{tabular}{|c|c|c|}
\hline $\begin{array}{l}\text { Citrus grandis (L.) Osbeck } \\
\text { (Rutaceae); 25,860/SRFC }\end{array}$ & Cancer $[19,20]$ & $\begin{array}{l}\text { Alkaloids, cardioglycosides, } \\
\text { saponins, tannins, terpenoids, } \\
\text { flavonoids, and steroids [21] }\end{array}$ \\
\hline
\end{tabular}

Citrus grandis (L.) Osbeck

Diabetes, cancer,

Cucurbita maxima Duch. (Cucurbitaceae); 42,449/HNC antihypertensive, antiinflammatory, immunomodulating, and bacterial infections $[22,23]$

Gastrointestinal disorders,

Dacryodes edulis (G. Don) H. J.
toothache, earache [27],
dysentery, anemia, leprosy, [28], Ethyl gallate and quercitrin [27] Lam (Burseraceae); 1874/SRFK skin diseases, and sickle cell disease [29]

Tannins, saponins, alkaloids [24], cucurbitaxanthin, gibberellin, and $\alpha$-tocopherol [25]

Antibacterial activity of petroleum ether, ethyl acetate, chloroform, ethanol, and leaf water: $E c, S a, P a, P m$ [21]

Antibacterial activity of aqueous seed extract: $E c, S a, K p, E f, P a$ [24], ethanol and aqueous extract of flowers: St, Ec, Ef, Bc [26]

Antibacterial activity of hydromethanolic, butanol, aqueous, ethanolic extract, ethyl acetate of bark: $E c, P a, B c, S a$ [27]
Hibiscus esculentus L. (Malvaceae); 42,823/HNC

Ipomoea batatas (L.) Lam (Convolvulaceae); 55,594/HNC

Irvingia gabonensis (Aubry. Lec. ex O. Rorke) Baill. (Irvingiaceae); 52,936/HNC
Inflammation, pain [30], cancer, hypoglycemic [31]

Antidiabetic, anti-inflammatory, reducing risk of cardiovascular disease, anticancer, reducing stomach stress, nausea, diarrhea [32]

Diarrhea, hernia, yellow fever, dysentery, antipoison [35, 36], gonorrhea, gastrointestinal and hepatic disorders, wound infections, diabetes, analgesic [37]
Antioxidant [39], cancer, Phaseolus vulgaris L. (Fabaceae); estrogenic, antidepressant [40], 42,587/HNC bacterial infections, tuberculosis [41]

Ricinodendron heudelotii (Baill.)

Pierre ex Heckel

(Euphorbiaceae); 50,852/HNC

Cough, antidote, intestinal

diseases [43], yellow fever, malaria, stomach pain, headache, dysentery [44]

Jaundice and liver problems,

hemorrhoids, dysentery, menorrhagia [45]

(Poaceae); 42,958/HNC

Diuretic, febrifuge, diarrheal diseases, dysentery,

Spondias mombin L.

(Anacardiaceae); 21,249/SRFK

hemorrhoids, gonorrhea, leucorrhea [47]

Theobroma cacao L.

(Sterculiaceae); 60,111/HNC
Cardiovascular, gastrointestinal, and nervous diseases [49]

Not reported

Caffeoylquinic acid [33], vitamin

E, beta-carotene, lutein, saponins [32], flavonoids, and chitinases

Not reported

[34]

Saponins, tannins, phenols, and phlobatannins [35], alkaloids, cardiac glycosides, anthraquinones, tannins, flavonoids [36], 3-friedelanone; betulinic acid; oleanolic acid; 3,3,4-tri-O-methylellagic acid; 3,4-di-O-methylellagic acid; hardwickiic acid [38]
Alkaloids, steroids, and flavonoids [42]

Antibacterial activity of aqueous and ethanol extract of leaves and bark: $S a, E c$ [36]; S: $B s t, C a, C f$, $\mathrm{Ea}, \mathrm{Ecl}, \mathrm{Mm}, \mathrm{Ng}, \mathrm{Pa}, \mathrm{Pm}, \mathrm{Pv}, \mathrm{Sa}$, $S d ; B c, B m, B s, C k, E c, K p, S f l, S t$, Sf [38]

Antibacterial activity of aqueous, alcohol, chloroform, ether extract of seeds: $S a, P a, S f, B s, K p$, Ec [41]

Tannins, polyphenols, alkaloids, glycosides, flavonoids, steroids, and saponins [43], aleuritolic acid, labda-8(17), 13-diem-3 $\beta$,

15-diol, $E$-ferulic acid octacosylate [44]

Flavonoids, saponins, tannins, and alkaloids [46]

Saponins, tannins, flavonoids, alkaloids, and glycosides [48]

Alkaloids, anthraquinones, cardiac glycosides, and saponins [50]
Antibacterial activity of methanol extract of the leaves: $S a, S f, P v, C f, M m, K o, K p, E c, P a$, St [43], Pf, Bs, Sa, Ec, Ca, Af [44], $E c, E a, P a, P s, K p, E c l$ [18]

Antibacterial activity of methanol extract of the stems: $E c$, $\mathrm{Kp}, \mathrm{Sa}, \mathrm{Pa}$ [46]

Antibacterial activity of ethanol, methanol, water, and acetone extracts of the leaves: $K p, S a, S t$, $\mathrm{Ea}, \mathrm{Sm}$ [48]

Antibacterial activity: $S a, E c, S d$, Kp, Sm, Pa, Pm [51] 
TABle 1: Continued.

\begin{tabular}{|c|c|c|c|}
\hline $\begin{array}{l}\text { Species (family); voucher } \\
\text { number }\end{array}$ & Traditional uses & $\begin{array}{l}\text { Bioactive or potentially bioactive } \\
\text { components }\end{array}$ & $\begin{array}{l}\text { Known antimicrobial activities of } \\
\text { plants }\end{array}$ \\
\hline $\begin{array}{l}\text { Uapaca guineensis Muell. Arg. } \\
\text { (Euphorbiaceae); 53,136/HNC }\end{array}$ & $\begin{array}{l}\text { Leprosy, epilepsy, edema, } \\
\text { rheumatism, aphrodisiac, fever, } \\
\text { inflammation, absorption [52] }\end{array}$ & $\begin{array}{l}\text { Steroids, alkaloid, terpenoids, } \\
\text { and gallic acid [53] }\end{array}$ & Not reported \\
\hline
\end{tabular}

TABLE 2: Bacterial strains and features.

\begin{tabular}{|c|c|c|}
\hline Bacteria & Features & References \\
\hline ATCC 25923 & Reference strain & - \\
\hline S. aureus MSSA1 & Clinical isolate: Met susceptible; $\mathrm{Nis}^{\mathrm{r}}, \mathrm{Chl}^{\mathrm{r}}$ & {$[8,9]$} \\
\hline S. aureus MRSA3 & Clinical isolate: $\mathrm{Ofxa}^{\mathrm{r}}, \mathrm{Kan}^{\mathrm{r}}, \mathrm{Tet}^{\mathrm{r}}, \mathrm{Erm}^{\mathrm{r}}$ & {$[8]$} \\
\hline S. aureus MRSA4 & Clinical isolate: $\mathrm{Ofxa}^{\mathrm{r}}, \mathrm{Kan}^{\mathrm{r}}, \mathrm{Cyp}^{\mathrm{r}}, \mathrm{Chl}^{\mathrm{r}}, \mathrm{Gen}^{\mathrm{r}}, \mathrm{Nis}^{\mathrm{r}}, \mathrm{Amp}^{\mathrm{r}}$ & {$[8,9]$} \\
\hline S. aureus MRSA6 & Clinical isolate: $\mathrm{Ofxa}^{\mathrm{r}}, \mathrm{Flx}^{\mathrm{r}}, \mathrm{Kan}^{\mathrm{r}}, \mathrm{Tet}^{\mathrm{r}}, \mathrm{Cyp}^{\mathrm{r}}, \mathrm{IM} / \mathrm{Cs}^{\mathrm{r}}, \mathrm{Chl}^{\mathrm{r}}, \mathrm{Gen}^{\mathrm{r}}, \mathrm{Nis}^{\mathrm{r}}, \mathrm{Amp}^{\mathrm{r}}$ & {$[8,9]$} \\
\hline S. aureus MRSA8 & Clinical isolate: $\mathrm{Ofxa}^{\mathrm{r}}, \mathrm{Flx}^{\mathrm{r}}, \mathrm{Kan}^{\mathrm{r}}, \mathrm{Erm}^{\mathrm{r}}, \mathrm{Cyp}^{\mathrm{r}}, \mathrm{Im} / \mathrm{Cs}^{\mathrm{r}}, \mathrm{Chl}^{\mathrm{r}}, \mathrm{Gen}^{\mathrm{r}}, \mathrm{Nis}^{\mathrm{r}}, \mathrm{Amp}^{\mathrm{r}}$ & {$[8,9]$} \\
\hline S. aureus MRSA9 & Clinical isolate: $\mathrm{Ofxa}^{\mathrm{r}}, \mathrm{Flx}^{\mathrm{r}}, \mathrm{Tet}^{\mathrm{r}}, \mathrm{Erm}^{\mathrm{r}}, \mathrm{Cyp}^{\mathrm{r}}, \mathrm{Im} / \mathrm{Cs}^{\mathrm{r}}, \mathrm{Chl}^{\mathrm{r}}, \mathrm{Gen}^{\mathrm{r}}, \mathrm{Nis}^{\mathrm{r}}, \mathrm{Amp}^{\mathrm{r}}$ & {$[8,9]$} \\
\hline S. aureus MRSA11 & Clinical isolate: $\mathrm{Ofxa}^{\mathrm{r}}, \mathrm{Kan}^{\mathrm{r}}, \mathrm{Erm}^{\mathrm{r}}, \mathrm{Cyp}^{\mathrm{r}}, \mathrm{Im} / \mathrm{Cs}^{\mathrm{r}}, \mathrm{Chl}^{\mathrm{r}}, \mathrm{Nis}^{\mathrm{r}}, \mathrm{Amp}^{\mathrm{r}}$ & {$[8,9]$} \\
\hline S. aureus MRSA12 & Clinical isolate: $\mathrm{Ofxa}^{\mathrm{r}}, \mathrm{Flx}^{\mathrm{r}}, \mathrm{Kan}^{\mathrm{r}}, \mathrm{Erm}^{\mathrm{r}}, \mathrm{Im} / \mathrm{Cs}^{\mathrm{r}}, \mathrm{Chl}^{\mathrm{r}}, \mathrm{Gen}^{\mathrm{r}}, \mathrm{Nis}^{\mathrm{r}}, \mathrm{Amp}^{\mathrm{r}}$ & {$[8,9]$} \\
\hline SA01 & Clinical isolate: $\mathrm{Erm}^{\mathrm{r}}, \mathrm{Amp}^{\mathrm{r}}$ & {$[54]$} \\
\hline SA07 & Clinical isolate: Erm $^{\mathrm{r}}$, Dox ${ }^{\mathrm{r}}$ & {$[54]$} \\
\hline SA18 & Clinical isolate: $\mathrm{Amp}^{\mathrm{r}}, \operatorname{Dox}^{\mathrm{r}}, \mathrm{Vm}^{\mathrm{r}}$ & {$[54]$} \\
\hline SA23 & Clinical isolate: $\operatorname{Imi}^{\mathrm{r}}$, Aug $^{\mathrm{r}}$ & {$[54]$} \\
\hline SA36 & Clinical isolate: $\operatorname{Dox}^{\mathrm{r}}, \mathrm{Vm}^{\mathrm{r}}$ & {$[54]$} \\
\hline SA39 & Clinical isolate: $\mathrm{Amp}^{\mathrm{r}}$ & {$[54]$} \\
\hline SA56 & Clinical isolate: $\mathrm{Amp}^{\mathrm{r}}$, Dox ${ }^{\mathrm{r}}$ & {$[54]$} \\
\hline SA64 & Clinical isolate: $\mathrm{Amp}^{\mathrm{r}}$, $\operatorname{Dox}^{\mathrm{r}}$ & [54] \\
\hline SA68 & Clinical isolate: $\mathrm{Amp}^{\mathrm{r}}, \mathrm{Vm}^{\mathrm{r}}$ & {$[54]$} \\
\hline SA88 & Clinical isolate: $\mathrm{Erm}^{\mathrm{r}}, \mathrm{Vm}^{\mathrm{r}}$ & {$[54]$} \\
\hline SA114 & Clinical isolate: $\mathrm{Amp}^{\mathrm{r}}, \mathrm{Dox}^{\mathrm{r}}$ & {$[54]$} \\
\hline SA116 & Clinical isolate: Erm $^{\mathrm{r}}$ & {$[54]$} \\
\hline SA124 & Clinical isolate: $\mathrm{Erm}^{\mathrm{r}}$ & {$[54]$} \\
\hline SA 126 & Clinical isolate: $\mathrm{Amp}^{\mathrm{r}}$, Dox ${ }^{\mathrm{r}}$ & {$[54]$} \\
\hline SA 127 & Clinical isolate: $\mathrm{Amp}^{\mathrm{r}}, \operatorname{Dox}^{\mathrm{r}}$ & {$[54]$} \\
\hline SA135 & Clinical isolate: Erm $^{\mathrm{r}}$ & {$[54]$} \\
\hline SA139 & Clinical isolate: Erm $^{\mathrm{r}}$ & {$[54]$} \\
\hline
\end{tabular}

$\mathrm{Chl}^{\mathrm{r}}, \mathrm{Cyp}^{\mathrm{r}}, \mathrm{Erm}^{\mathrm{r}}, \mathrm{Flx}^{\mathrm{r}}, \mathrm{Im} / \mathrm{Cs}^{\mathrm{r}}, \operatorname{Kan}^{\mathrm{r}}, \operatorname{Met}^{\mathrm{r}}, \mathrm{Ofxa}^{\mathrm{r}}, \operatorname{Tet}^{\mathrm{r}}, \mathrm{Vm}^{\mathrm{r}}, \mathrm{Amp}^{\mathrm{r}}, \operatorname{Dox}^{\mathrm{r}}, \operatorname{Aug}^{\mathrm{r}}, \mathrm{Gen}^{\mathrm{r}}$, and Nis ${ }^{\mathrm{r}}$ resistance to chloramphenicol, ciprofloxacin, erythromycin, flomoxef, imipenem/cilastatin sodium, kanamycin, methicillin, ofloxacin, tetracycline, vancomycin, ampicillin, doxycycline, augmentin, gentamicin, and nisin, respectively, SA: Staphylococcus aureus.

\subsection{INT Colorimetric Assay for MIC and Minimal Bactericidal} Concentration (MBC) Determinations. The MIC and minimal bactericidal concentration (MBC) determinations on various strains of $S$. aureus were performed using the rapid INT colorimetric assay [56] with some modifications as previously described $[14,38]$. The samples were dissolved in DMSO/MHB. The final concentration of DMSO was lower than $2.5 \%$. The twofold dilutions of the samples were made in a 96-well microplate, and the tested bacterial concentration was $1.5 \times 10^{6}$ colony-forming unit $(\mathrm{CFU}) / \mathrm{mL}$. The microplates were incubated at $37^{\circ} \mathrm{C}$ for $18 \mathrm{~h}$. All assays were performed in triplicate and repeated thrice. Wells containing $\mathrm{MHB}, 100 \mu \mathrm{L}$ of inoculum, and DMSO to a final concentration of $2.5 \%$ served as negative control. The MIC of each sample was detected after $18 \mathrm{~h}$ incubation at $37^{\circ} \mathrm{C}$, following addition $(40 \mu \mathrm{L})$ of $0.2 \mathrm{mg} / \mathrm{mL}$ of INT and incubation at $37^{\circ} \mathrm{C}$ for 30 minutes as the lowest sample concentration that prevented the color change of the medium and exhibited complete inhibition of microbial growth [56]. The MBC was determined by adding $50 \mu \mathrm{L}$ aliquots of the preparations, which did not show any growth after incubation during MIC assays, to $150 \mu \mathrm{L}$ of $\mathrm{MHB}$. These preparations were further incubated at $37^{\circ} \mathrm{C}$ for $48 \mathrm{~h}$. The $\mathrm{MBC}$ was regarded as the lowest concentration of samples, which did not produce a color change after addition of INT as mentioned above $[57,58]$.

2.6. Evaluation of the Role of Efflux Pumps in the Resistance of Selected Bacteria. To evaluate the involvement of efflux 
TABLE 3: Extraction yields and phytochemical composition of the plant extracts.

\begin{tabular}{|c|c|c|c|c|c|c|c|c|c|c|}
\hline \multicolumn{2}{|c|}{ Plant extract and part used } & \multirow{2}{*}{$\begin{array}{c}\begin{array}{c}\text { Yields } \\
(\%)\end{array} \\
10.3\end{array}$} & \multirow{2}{*}{$\frac{\text { Alkaloids }}{+}$} & \multirow{2}{*}{$\begin{array}{c}\text { Polyphenols } \\
+\end{array}$} & \multirow{2}{*}{$\begin{array}{c}\text { Flavonoids } \\
-\end{array}$} & \multirow{2}{*}{$\begin{array}{c}\text { Anthraquinones } \\
-\end{array}$} & \multirow{2}{*}{$\begin{array}{c}\text { Tannins } \\
+\end{array}$} & \multirow{2}{*}{$\begin{array}{c}\text { Triterpenes } \\
-\end{array}$} & \multirow{2}{*}{$\begin{array}{c}\text { Steroids } \\
+\end{array}$} & \multirow{2}{*}{$\frac{\text { Saponins }}{+}$} \\
\hline Azadirachta indica & Bark & & & & & & & & & \\
\hline Citrus grandis & Leaves & 2.6 & + & + & - & - & + & + & + & - \\
\hline \multirow[t]{2}{*}{ Cucurbita maxima } & Beans & 2.6 & - & + & - & - & + & + & + & + \\
\hline & Leaves & 6.2 & - & + & + & + & + & + & + & + \\
\hline \multirow[t]{2}{*}{ Dacryodes edulis } & Bark & 9.1 & - & + & - & + & + & + & + & + \\
\hline & Seeds & 6.9 & - & + & + & + & + & + & + & + \\
\hline Hibiscus esculentus & Leaves & 1.9 & - & + & - & - & + & - & + & - \\
\hline Ipomoea batatas & Beans & 3.3 & + & + & + & + & + & + & - & + \\
\hline Irvingia gabonensis & Leaves & 6.7 & - & + & - & - & + & - & + & + \\
\hline Phaseolus vulgaris & Leaves & 1.2 & - & + & - & - & + & - & + & + \\
\hline Ricinodendron & Bark & 2.9 & - & + & + & + & + & + & + & - \\
\hline heudelotii & Leaves & 7.2 & - & + & + & + & + & + & + & + \\
\hline \multirow{2}{*}{$\begin{array}{l}\text { Spondias mombin } \\
\text { Saccharum } \\
\text { officinarum }\end{array}$} & Leaves & 21.4 & - & + & - & - & + & + & + & - \\
\hline & Leaves & 8.4 & - & + & - & - & + & - & + & + \\
\hline \multirow{2}{*}{ Theobroma cacao } & Leaves & 3.1 & - & + & - & - & + & + & + & + \\
\hline & Beans & 6.2 & + & + & + & + & + & + & + & + \\
\hline \multirow{2}{*}{ Uapaca guineensis } & Leaves & 7.3 & - & + & - & - & + & + & + & + \\
\hline & Bark & 6.1 & + & + & - & - & + & + & + & + \\
\hline
\end{tabular}

-: absent; +: present; yield calculated as the ratio of the mass of the obtained methanol extract/mass of the plant powder.

pumps in the resistance of selected bacterial strains to some of the active plant extracts, Dacryodes edulis seeds (DES), Hibiscus esculentus leaves (HEL), Uapaca guineensis leaves (UGL), Uapaca guineensis bark (UGB), and CIP (reference drug) were tested in the absence or presence of EPI (CCCP $(0.5 \mu \mathrm{g} / \mathrm{mL})$ or CPZ $(25 \mu \mathrm{g} / \mathrm{mL}))$. MICs of samples alone or in combination with EPI were determined as above, and the increase in activity was determined as the ratio of MIC of sample alone versus sample in combination with EPI. All assays were performed in triplicate and repeated thrice.

2.7. Antibiotic Activity Modulation Assays. To evaluate the antibiotic resistance modulation activity of the most active extracts: Azadirachta indica bark (AIB), Dacryodes edulis seeds (DES), Dacryodes edulis bark (DEB), Dacryodes edulis leaves (DEL), Phaseolus vulgaris leaves (PVL), Ricinodendron heudelotii leaves (RHL), and Uapaca guineensis bark (UGB), a preliminary assay was performed in order to assess the MICs of antibiotics in the absence and presence of these extracts using the broth microdilution method as previously described $[14,38,56]$. S. aureus SA 88 was used for the preliminary assay, and the samples were tested at various subinhibitory concentrations (MIC/2, MIC/4, MIC/8, and MIC/16). Results allowed to select DEB, DEL, DES, RHL, and UGB to be tested further against $S$. aureus ATCC 25923, and 8 resistant strains of S. aureus (MRSA3, MRSA4, MRSA9, MRSA11, MRSA12, SA18, SA36, and SA64) at MIC/2 and MIC/4. Briefly, after serial dilutions of antibiotics, extract was added to each well at its subinhibitory concentrations, the bacterial inoculation was done, and the MIC was determined. Rows receiving antibiotic dilutions without extracts were used for the determination of the MICs of the antibiotics. The modulation factor was defined as the ratio of the MIC of antibiotic alone versus that of antibiotic in the presence of extract. Modulation factor $\geq 2$ was set as the cutoff for biologically significance of antibiotic resistance-modulating effects [59].

\section{Results}

3.1. Phytochemical Composition of Plant Extracts. The major classes of phytochemicals were screened in the 18 studied plant extracts (Table 3 ). It appears that all extracts contained polyphenols and tannins. Other classes of phytochemicals were selectively present. Only the extract of the beans of Theobroma cacao contained all the investigated classes of secondary metabolites.

3.2. Antibacterial Activity. The antibacterial activities of the 18 tested extracts and ciprofloxacin against 26 strains of S. aureus are summarized in Table 4. It appears that extracts from Dacryodes edulis seeds (DES) and Dacryodes edulis bark (DEB), within a MIC range of $256-1024 \mu \mathrm{g} / \mathrm{mL}$, and ciprofloxacin (MIC below $4 \mu \mathrm{g} / \mathrm{mL}$ ), were active against all 26 tested bacterial strains. Other extracts were selectively active, and MIC values varied from 64 to $1024 \mu \mathrm{g} / \mathrm{mL}$ against 25/26 (96.2\%) tested bacteria for Phaseolus vulgaris leaves (PVL), 24/26 (92.3\%) for Azadirachta indica bark (AIB), Dacryodes edulis leaves (DEL), and Ricinodendron heudelotii leaves (RHL), 23/26 (88.5\%) for Hibiscus esculentus leaves (HEL), 19/26 (73.1\%) for Uapaca guineensis leaves (UGL), 18/26 (69.2\%) for Ricinodendron heudelotii bark (RHB) and Uapaca guineensis bark (UGB), 17/26 (61.5\%) for Saccharum officinarum leaves (SOL), 16/26 (61.5\%) for Ipomoea batatas leaves (IBL) and Theobroma cacao leaves (TCL), 15/26 (57.7\%) for Citrus grandis leaves (CGL), 14/26 (53.8\%) for Theobroma cacao beans (TCB), 12/26 (46.2\%) for Cucurbita maxima beans (CMB), 10/26 (38.5\%) for Spondias mombin leaves (SML), and 7/26 (26.9\%) for Irvingia gabonensis beans 


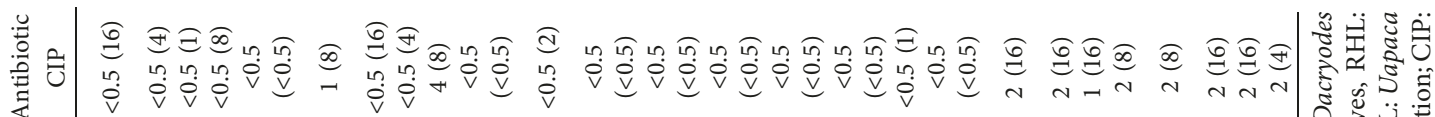
⿹

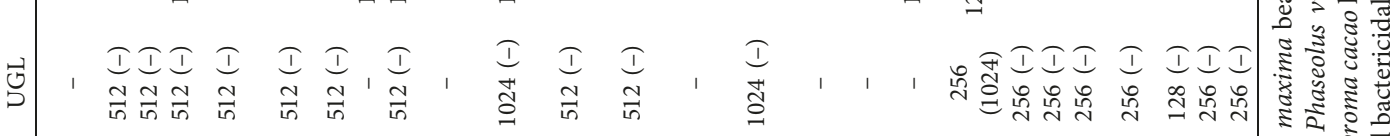
U. 0 , I II 苞 | 㞼

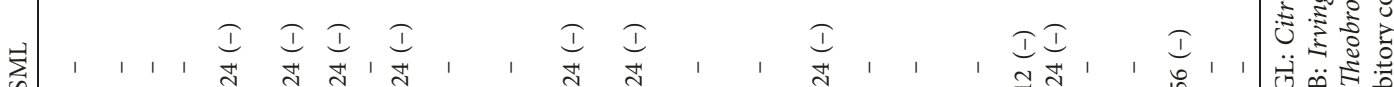

के

芯芯芯芯'

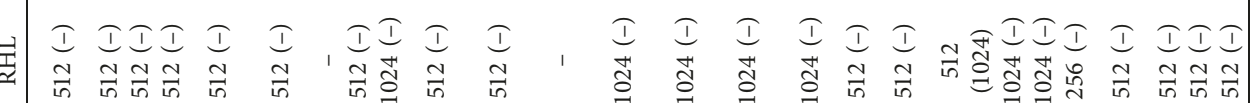
ठ웡 I

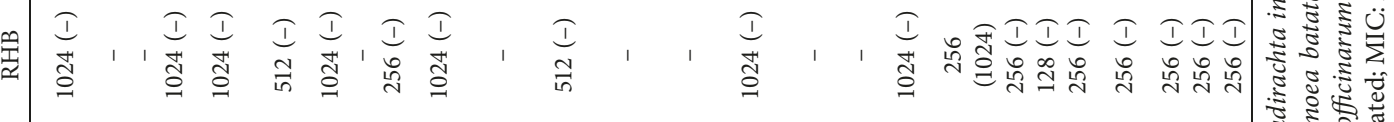

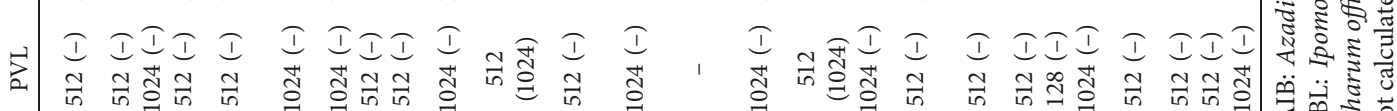
II I I 蛋

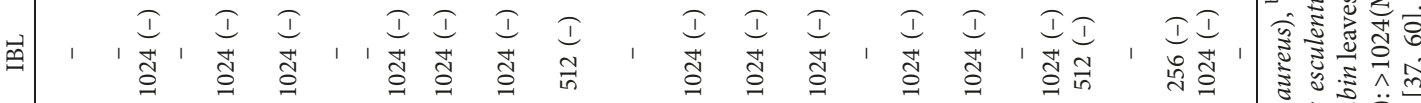

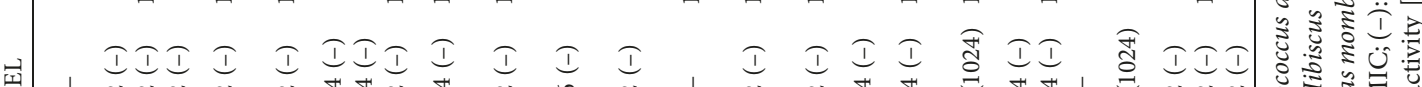

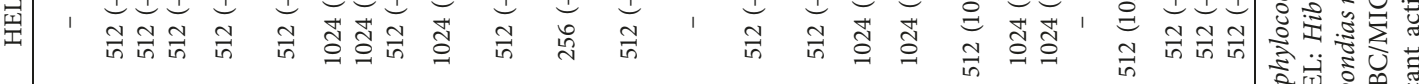

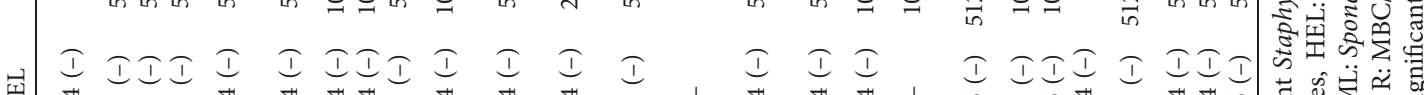

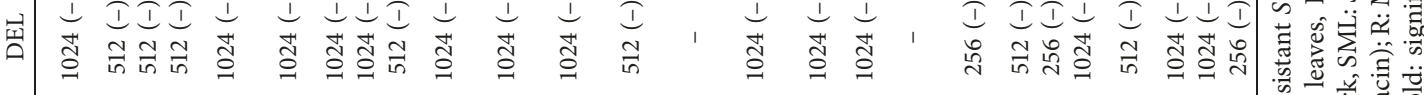

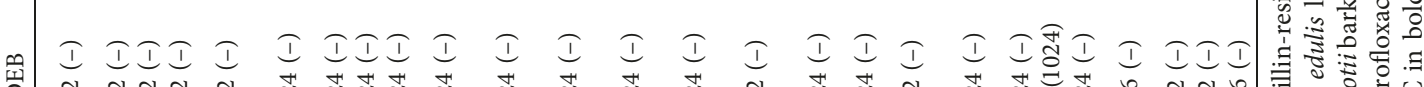

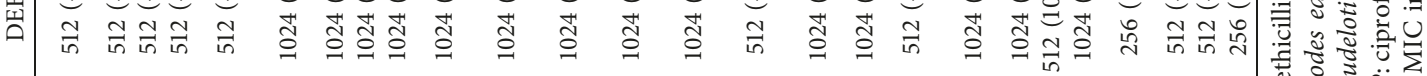

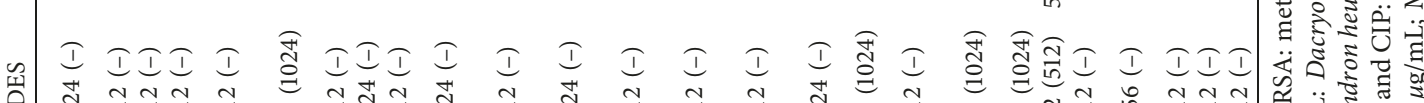

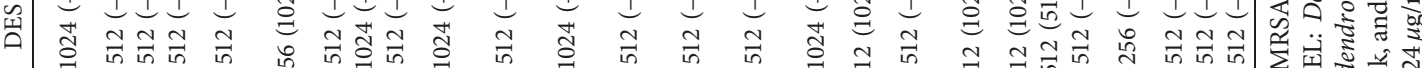

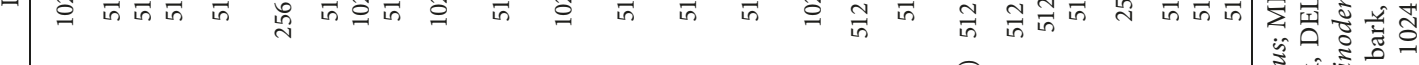

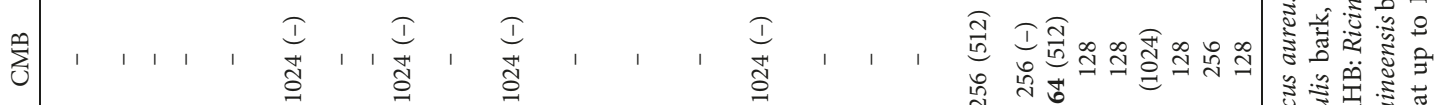

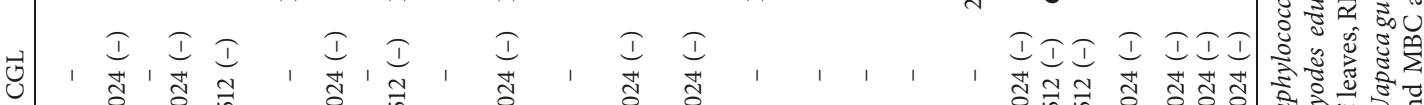

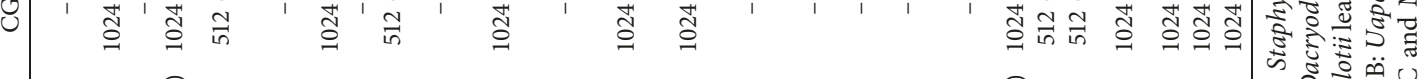

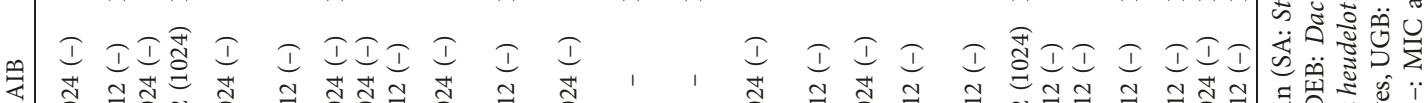

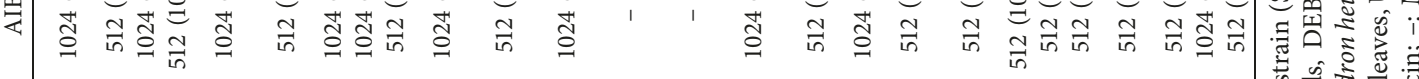

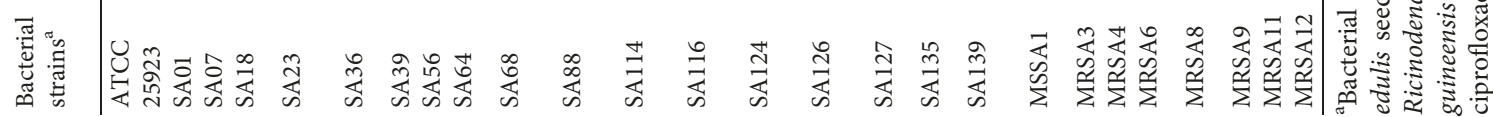


TABLE 5: MIC of extracts and ciprofloxacin in the absence $(-)$ and presence $(+)$ of carbonyl cyanide $m$-chlorophenyl hydrazone (CCCP) against selected strains of Staphylococcus aureus.

\begin{tabular}{|c|c|c|c|c|c|c|c|c|c|c|}
\hline \multirow{3}{*}{ Bacterial strains ${ }^{\mathrm{a}}$} & \multicolumn{10}{|c|}{ Samples ${ }^{\mathrm{b}}$ and MIC in $\mu \mathrm{g} / \mathrm{mL}$ and fold increase of activity (in parentheses) } \\
\hline & \multicolumn{2}{|c|}{ DES } & \multicolumn{2}{|c|}{ HEL } & \multicolumn{2}{|c|}{ UGB } & \multicolumn{2}{|c|}{ UGL } & \multicolumn{2}{|c|}{ CIP } \\
\hline & - & + & - & + & - & + & - & + & - & + \\
\hline ATCC 25923 & 256 & $32(32)$ & 256 & $<8(>32)$ & - & $<8(>128)$ & 1024 & $<8(>128)$ & 2 & $1(2)$ \\
\hline MRSA3 & 256 & $<8(>32)$ & 256 & $<8(>32)$ & 512 & $<8(>64)$ & 512 & $<8(>64)$ & 1 & $<0.5(>2)$ \\
\hline MRSA4 & 256 & $16(16)$ & 128 & $16(8)$ & 1024 & $128(8)$ & 1024 & $64(16)$ & 2 & $<0.5(>4)$ \\
\hline MRSA6 & 128 & $<8(>16)$ & 256 & $<8(>32)$ & 1024 & $<8(>128)$ & 512 & $<8(>64)$ & 1 & $<0.5(>2)$ \\
\hline MRSA8 & 256 & $128(2)$ & 128 & $128(1)$ & - & $512(>2)$ & 512 & $128(>4)$ & $<0.5$ & $<0.5$ (nd) \\
\hline MRSA9 & 128 & $<8(>16)$ & 64 & $<8(>8)$ & 1024 & $<8(>128)$ & 256 & $<8(>32)$ & $<0.5$ & $<0.5$ (nd) \\
\hline MRSA11 & 256 & $<8(>32)$ & 128 & $<8(>16)$ & 1024 & $<8(>128)$ & 256 & $<8(>32)$ & 1 & 1(1) \\
\hline MRSA12 & 256 & $<8(>32)$ & 128 & $<8(>16)$ & 1024 & $<8(>128)$ & 256 & $<8(>32)$ & $<0.5$ & $<0.5$ (nd) \\
\hline SA01 & 128 & $<8(>16)$ & 128 & $<8(>16)$ & 1024 & $<8(>128)$ & 256 & $<8(>32)$ & $<0.5$ & $<0.5$ (nd) \\
\hline SA07 & 512 & $<8(>64)$ & 512 & $512(1)$ & 512 & $512(1)$ & 256 & $<8(>32)$ & $<0.5$ & $<0.5$ (nd) \\
\hline SA18 & 1024 & $128(8)$ & 256 & $128(2)$ & 1024 & $512(2)$ & 512 & $<8(>64)$ & 1 & $<0.5(>2)$ \\
\hline SA 88 & 512 & $512(1)$ & - & - & 1024 & $1024(1)$ & 1024 & $256(>4)$ & 1 & $<0.5(>2)$ \\
\hline SA114 & 1024 & $<8(>128)$ & - & - & 1024 & $128(8)$ & 512 & $<8(>64)$ & $<0.5$ & $<0.5(>2)$ \\
\hline SA135 & 512 & $64(8)$ & - & - & - & $128(>8)$ & 512 & $<8(>64)$ & 1 & $<0.5(>2)$ \\
\hline
\end{tabular}

${ }^{a}$ Bacterial strain (SA: Staphylococcus aureus; MRSA: methicillin-resistant Staphylococcus aureus), bamples (DES: Dacryodes edulis seeds, HEL: Hibiscus esculentus leaves, UGL: Uapaca guineensis leaves, UGB: Uapaca guineensis bark, and CIP: ciprofloxacin); MIC: minimal inhibitory concentration; CCCP was tested at $0.5 \mu \mathrm{g} / \mathrm{mL} ;(-)$ : $>1024 \mu \mathrm{g} / \mathrm{mL}$; values in bold represent increase of activity $\geq 2$.

TABLE 6: MIC of extracts and ciprofloxacin in the absence (-) and presence $(+)$ of chlorpromazine (CPZ) against selected strains of Staphylococcus aureus.

\begin{tabular}{|c|c|c|c|c|c|c|c|c|c|c|}
\hline \multirow{3}{*}{ Bacterial strains ${ }^{\mathrm{a}}$} & \multicolumn{10}{|c|}{ Samples ${ }^{\mathrm{b}}$ and MIC in $\mu \mathrm{g} / \mathrm{mL}$ and fold increase of activity (in parentheses) } \\
\hline & \multicolumn{2}{|c|}{ DES } & \multicolumn{2}{|c|}{ HEL } & \multicolumn{2}{|c|}{ UGB } & \multicolumn{2}{|c|}{ UGL } & \multicolumn{2}{|c|}{ CIP } \\
\hline & - & + & - & + & - & + & - & + & - & + \\
\hline ATCC 25923 & 512 & $512(1)$ & - & - & 512 & $512(1)$ & 128 & $1024(0.13)$ & 2 & $2(1)$ \\
\hline MRSA3 & 256 & $256(1)$ & 1024 & $1024(1)$ & 512 & $512(1)$ & - & - & 4 & $4(1)$ \\
\hline MRSA4 & 512 & $512(1)$ & - & - & 256 & $256(1)$ & 1024 & $1024(1)$ & 2 & $2(1)$ \\
\hline MRSA6 & 256 & $256(1)$ & 512 & $128(2)$ & 512 & $512(1)$ & 256 & $-(0.25)$ & 2 & $2(1)$ \\
\hline MRSA8 & 256 & $256(1)$ & 1024 & $1024(1)$ & 256 & $256(1)$ & - & - & 1 & $2(0.5)$ \\
\hline MRSA9 & 256 & $256(1)$ & 1024 & $1024(1)$ & 512 & $512(1)$ & 256 & $-(0.25)$ & 1 & $2(0.5)$ \\
\hline MRSA11 & 512 & $512(1)$ & 1024 & $1024(1)$ & 512 & $512(1)$ & 128 & $-(<0.13)$ & 4 & $4(1)$ \\
\hline MRSA12 & 512 & $512(1)$ & - & - & 512 & $512(1)$ & - & - & 2 & $2(1)$ \\
\hline SA01 & 512 & $512(1)$ & 1024 & $1024(1)$ & 512 & $512(1)$ & 512 & $512(1)$ & 1 & $1(1)$ \\
\hline SA07 & 512 & $512(1)$ & 1024 & $1024(1)$ & 512 & $512(1)$ & 1024 & $1024(1)$ & 4 & $4(1)$ \\
\hline SA18 & 512 & $512(1)$ & - & - & 1024 & $1024(1)$ & - & - & 1 & $1(1)$ \\
\hline SA88 & 512 & $512(1)$ & - & - & 1024 & $1024(1)$ & - & - & 4 & $4(1)$ \\
\hline SA114 & 1024 & $1024(1)$ & - & - & 1024 & $1024(1)$ & - & - & 1 & $1(1)$ \\
\hline SA135 & 512 & $512(1)$ & - & - & 1024 & $1024(1)$ & - & - & 1 & $1(1)$ \\
\hline
\end{tabular}

${ }^{\mathrm{a} B a c t e r i a l ~ s t r a i n ~(S A: ~ S t a p h y l o c o c c u s ~ a u r e u s ; ~ M R S A: ~ m e t h i c i l l i n-r e s i s t a n t ~ S t a p h y l o c o c c u s ~ a u r e u s) ; ~}{ }^{\mathrm{b}}$ samples (DES: Dacryodes edulis seeds, HEL: Hibiscus esculentus leaves, UGL: Uapaca guineensis leaves, UGB: Uapaca guineensis bark, CIP: ciprofloxacin); CPZ: chlorpromazine at $25 \mu \mathrm{g} / \mathrm{mL}$; CIP: ciprofloxacin; MIC: minimal inhibitory concentration.

(IGB). The lowest MIC value of $64 \mu \mathrm{g} / \mathrm{mL}$ was obtained with CMB against MRSA4 strain and UGB against MRSA9 strain.

3.3. Role of Efflux Pumps in the Resistance of Strains of S. aureus. Four extracts (DES, HEL, UGL, and UGB) and CIP (reference drug) were tested in the absence or presence of CCCP $(0.5 \mu \mathrm{g} / \mathrm{mL})$ and CPZ $(25 \mu \mathrm{g} / \mathrm{mL})$ to evaluate the role of efflux pumps in the resistance of 14 tested $S$. aureus strains. The results are summarized in Tables 5 and 6 . It appears that CCCP significantly improved the activity of the 4 tested extracts against the majority of $S$. aureus strains (Table 5). The increase of activity in the presence of CCCP ranged from 2 -fold to $>128$-fold. The highest increase of activity ( $>128$-fold) was obtained when DES, UGB, and UGL were tested in the presence of CCCP on at least one S. aureus strain. In contrast, in the presence of $\mathrm{CPZ}$, no improvement in the activity of the four extracts was observed (Table 6). This is clear indication that CCCP was the appropriate EPI of the studied $S$. aureus strains.

3.4. Antibiotic Resistance Modulation Activity of Extracts. Seven plant extracts, AIB, DES, DEB, DEL, PVL, RHL, and $\mathrm{UGB}$, at their various subinhibitory concentrations $(\mathrm{MIC} / 2$, $\mathrm{MIC} / 4, \mathrm{MIC} / 8$, and $\mathrm{MIC} / 16$ ) were first tested in 
combination with 8 antibiotics: CHL, TET, CIP, AMP, CEF, ERY, STR, and KAN against $S$. aureus SA88 strain. The results summarized in Table S1 (Supplementary Materials) show that better modulation of the activity of antibiotics was obtained with all extracts at MIC/2 and MIC/4. At their $\mathrm{MIC} / 2$, 2-fold or more increase of antibiotic activities was obtained with PVL, AIB, DEB, DES, DEL, UGB, and RHL and $2,4,4,6,6,7$, and 8 of the 8 tested antibiotics, respectively (Table S1; Supplementary Materials). Consequently, the most active extracts, DEB, DEL, DES, RHL, and UGB, were further tested in combination with the above 8 antibiotics against the reference strains (ATCC 25923) and 8 resistant strains of $S$. aureus at $\mathrm{MIC} / 2$ and $\mathrm{MIC} / 4$ (Tables S2-S6; Supplementary Materials). Results showed that 2-fold or more antibiotic-modulating effects against more than $70 \%$ of the S. aureus strains tested were obtained when DEB was combined with CHL at MIC/2 (77.78\%; Table S2; Supplementary Materials), when DEL was combined with CHL and STR at MIC/2 (77.78\%; Table S3; Supplementary Materials), when DES was combined with CIP (77.78\% at MIC/2), CHL (100\% and 88.89 at MIC/2 and $\mathrm{MIC} / 4$ resp.), TET (77.78\% at MIC/2 and MIC/4), and STR (88.89\% and $77.78 \%$ at MIC/2 and MIC/4 resp.) (Table S4; Supplementary Materials), when RHL was combined with CIP, ERY, and KAN $(88.89 \%$ and $77.78 \%$ at MIC/2 and $\mathrm{MIC} / 4$ resp.), CHL (88.89\% at MIC/2 and MIC/4), TET (77.78\% at MIC/2 and MIC/4), and STR (88.89\% at MIC/2) (Table S5; Supplementary Materials), and when UGB was combined with CHL, KAN, and STR $(77.78 \%$ at MIC/2 and MIC/4) (Table S6; Supplementary Materials).

\section{Discussion}

4.1. Phytochemical Composition of Extracts. Polyphenols and tannins were detected in all extracts. The role of several molecules belonging to polyphenols as antibacterials has been demonstrated [10, 11, 38, 61]. Tannins also belong to a class of polyphenols, and its presence in all extracts could in part explain the fact that all the tested extracts were active in at least one strain of the tested bacteria [10]. However, it should be made clear that the presence of a class of secondary metabolite with reported antibacterial effect is not a guarantee of the good activity of a plant. The antibacterial effect depends on the structure and the amount of a particular phytochemical in the plant or possible interactions with other compounds. This could explain why the extract from the beans of Theobroma cacao that contained all the investigated classes of secondary metabolites (Table 3) was not the most active sample (Table 4).

4.2. Antibacterial Potential of Extracts. Resistance of bacteria to antibiotics propels the search of new agents to fight against MDR phenotypes. In the present study, clinical strains of $S$. aureus used were previously reported as resistant to at least one commonly used antibiotic $[8,9]$ (Table 2). Several locally isolated strains of $S$. aureus [54] were used herein, to better adapt the study to our environment. According to established criteria, MIC values in the range of $100-1000 \mu \mathrm{g} / \mathrm{mL}$ are indication that plant extracts bear antimicrobial activities [62]. Also, the antibacterial activity of botanicals is considered significant if MIC values are below $100 \mu \mathrm{g} / \mathrm{mL}$, moderate if $100 \leq$ MICs $\leq 625 \mu \mathrm{g} / \mathrm{mL}$, and weak if MICs $>625 \mu \mathrm{g} / \mathrm{mL}$ $[37,60]$. On these bases, it can be deduced that all the tested plant extracts had antistaphylococcal activities, except Irvingia gabonensis beans (IGB), with MICs above $1000 \mu \mathrm{g} / \mathrm{mL}$ against all tested strains of S. aureus (Table 4). This activity was significant for CMB against MRSA4 strain and UGB against MRSA9 strain (MIC: $64 \mu \mathrm{g} / \mathrm{mL}$ ). Most of the recorded MIC values ranged from 512 to $1024 \mu \mathrm{g} / \mathrm{mL}$, indicating that extracts rather exhibited moderate to low antistaphylococcal effects. However, this activity could be considered important because the clinical strains of $S$. aureus used were resistant phenotypes while extracts were from edible plants. In effect, it was suggested that if botanicals are food plants, as they are allegedly nontoxic or less toxic than other medicinal plants, their antibacterial activity is significant in a range of $100 \leq \mathrm{MIC} \leq 512 \mu \mathrm{g} / \mathrm{mL}$ and moderately active in a range of $512<\mathrm{MIC} \leq 2048 \mu \mathrm{g} / \mathrm{mL}$ [63].

4.3. Role of Efflux Pumps in Susceptibility of S. aureus Strains to the Extracts. Bacterial efflux systems are associated with major human health concerns as they are involved in the resistance of pathogenic bacteria such as S. aureus [64-66]. Previously, inhibition of efflux pumps by natural products has been found to improve the activity of antibiotics against $S$. aureus. For example, inhibition of the TetK efflux pump was reported with the essential oil of Chenopodium ambrosioides and its constituent $\alpha$-terpinene against $S$. aureus IS-58 strain [66]. In the present study, two well-known EPIs (CCCP and $\mathrm{CPZ}$ ) were used to assess the implication of efflux pumps in the resistance of the studied $S$. aureus strains to plant extracts. CCCP is an inhibitor of the proton-motive force of ATPbinding cassette $(\mathrm{ABC})$ transporters of several Gram-negative and Gram-positive bacteria, including S. aureus [5-7]. CPZ is capable of reversing or reducing the antibiotic resistance of bacteria including S. aureus [67], due to its indirect effects on ATPase activity that is dependent upon $\mathrm{Ca}^{2+}$ [68]. In the present study, it was found that CCCP contrary to CPZ improved the activity of the four extracts (DES, HEL, UGL, and UGB) (Tables 5 and 6). This indicates that ABC transporters are involved in the resistance of the studied strains of S. aureus and that combination of extracts such as HEL, UGL, and UGB with an inhibitor of $\mathrm{ABC}$ transporters could improve the antistaphylococcal fight.

4.4. Antibiotic Modulation Effects of Extracts. The antibiotic resistance-modulating effects of several botanicals and phytochemicals against resistant bacteria have been documented $[12-15,59,69]$. It has been suggested that extracts capable of potentiating the activity of antibiotics on more than $70 \%$ of bacteria could be potential efflux pump inhibitors [70]. In this study, antibiotic modulation activity of extracts at their MIC/2 on more than $70 \%$ tested strains of $S$. aureus was obtained with the association of DEB and DEL and with $1 / 8$ (12.5\%) tested antibiotics (Tables S2 and S3; Supplementary Materials), UGB with 2/8 (25\%) antibiotics (Table S6; Supplementary Materials), 
DES with 4/8 (50\%) antibiotics (Table S4; Supplementary Materials), and RHL with 6/8 (75\%) antibiotics (Table S5; Supplementary Materials). Hence, the tested extracts and mostly RHL may act as efflux pump inhibitors [70]. The use of CCCP indicated that $\mathrm{ABC}$ transporters were the efflux pumps involved in the resistance of the tested bacteria, suggesting that the above extract could be the inhibitors of such pumps. The potential of the $R$. heudelotii leaf extract (RHL) to reverse antibiotic resistance in Gram-negative MDR bacteria was previously reported [18]. The present study therefore provides more information about the ability of this plant to modulate the activity of antibiotics against resistant strains of $S$. aureus.

\section{Conclusion}

In conclusion, the present work provides informative data about the antistaphylococcal potential of 13 Cameroonian food plants. It also indicates that some extracts such as DES, HEL, UGL, and UGB could be used in combination with EPI to combat resistance of Staphylococcus aureus to antibiotics. Finally, this study also demonstrates that some studied extracts and mostly RHL could be used as antibiotic resistance modulators, providing a new weapon against the resistance of $S$. aureus to antibiotics.

\section{Abbreviations}

$\begin{array}{ll}\text { AIB: } & \text { Azadirachta indica bark } \\ \text { AMP: } & \text { Ampicillin } \\ \text { ATCC: } & \text { American Type Culture Collection } \\ \text { CCCP: } & \text { Carbonyl cyanide } m \text {-chlorophenyl hydrazone } \\ \text { CEF: } & \text { Cefepime } \\ \text { CFU: } & \text { Colony-forming unit } \\ \text { CGL: } & \text { Citrus grandis } \\ \text { CHL: } & \text { Chloramphenicol } \\ \text { CIP: } & \text { Ciprofloxacin } \\ \text { CMB: } & \text { Cucurbita maxima beans } \\ \text { CPZ: } & \text { Chlorpromazine } \\ \text { DEB: } & \text { Dacryodes edulis bark } \\ \text { DEL: } & \text { Dacryodes edulis leaves } \\ \text { DES: } & \text { Dacryodes edulis seeds } \\ \text { DMSO: } & \text { Dimethylsulfoxide } \\ \text { EPI: } & \text { Efflux pump inhibitors } \\ \text { ERY: } & \text { Erythromycin } \\ \text { HEL: } & \text { Hibiscus esculentus leaves } \\ \text { IBL: } & \text { Ipomoea batatas leaves } \\ \text { IGB: } & \text { Irvingia gabonensis beans } \\ \text { INT: } & \text { p-Iodonitrotetrazolium chloride } \\ \text { KAN: } & \text { Kanamycin } \\ \text { MBC: } & \text { Minimal bactericidal concentration } \\ \text { MDR: } & \text { Multidrug-resistant } \\ \text { MHB: } & \text { Mueller Hinton broth } \\ \text { MIC: } & \text { Minimal inhibitory concentration } \\ \text { MRSA: } & \text { Methicillin-resistant Staphylococcus aureus } \\ \text { PVL: } & \text { Phaseolus vulgaris leaves } \\ \text { RA: } & \text { Reference antibiotics } \\ \text { RHB: } & \text { Ricinodendron heudelotii bark } \\ \text { RHL: } & \text { Ricinodendron heudelotii leaves } \\ \text { SA: } & \text { Staphylococcus aureus } \\ & \end{array}$

SML: $\quad$ Spondias mombin leaves

SOL: Saccharum officinarum leaves

STR: Streptomycin

TCB: Theobroma cacao beans

TCL: Theobroma cacao leaves

TET: Tetracycline

UGB: Uapaca guineensis bark

UGL: Uapaca guineensis leaves.

\section{Data Availability}

The data used to support the findings of this study are included within the article.

\section{Conflicts of Interest}

The authors declare that they have no conflicts of interest.

\section{Authors' Contributions}

Brice E. N. Wamba, Paul Nayim, Joachim K. Dzotam, and Ornella J. T. Ngalani carried out the study. Armelle T. Mbaveng and Victor Kuete designed the experiments. Armelle T. Mbaveng and Victor Kuete wrote the manuscript. Armelle T. Mbaveng and Victor Kuete supervised the work and provided the bacterial strains. All authors read and approved the final manuscript.

\section{Acknowledgments}

The authors are thankful to the Cameroon National Herbarium for identification of plants and also thank Dr. Jean P. Dzoyem (University of Dschang, Cameroon) for providing the MRSA strains of $S$. aureus.

\section{Supplementary Materials}

Preliminary evaluation of antibiotic resistance modulatory activity of extracts against $S$. aureus SA88 (Table S1); antibiotic resistance modulatory activity of the bark methanol extract from Dacryodes edulis bark (DEB) (Table S2); the leaf methanol extract from Dacryodes edulis leaves (DEL) (Table S3); the seed methanol extract from Dacryodes edulis seeds (DES) (Table S4); the leaf methanol extract from Ricinodendron heudelotii leaves (RHL) (Table S5); and the bark methanol extract from Uapaca guineensis bark (UGB) (Table S6) at their $\mathrm{MIC} / 2$ and $\mathrm{MIC} / 4$ on selected strains of Staphylococcus aureus. (Supplementary Materials)

\section{References}

[1] V. G. Fowler Jr., L. L. Sanders, D. J. Sexton et al., "Outcome of Staphylococcus aureus bacteremia according to compliance with recommendations of infectious diseases specialists: experience with 244 patients," Clinical Infectious Diseases, vol. 27, no. 3, pp. 478-486, 1998.

[2] R. Jenkins, N. Burton, and R. Cooper, "Manuka honey inhibits cell division in methicillin-resistant Staphylococcus aureus," Journal of Antimicrobial Chemotherapy, vol. 66, no. 11, pp. 2536-2542, 2011. 
[3] A. P. Johnson, "Methicillin-resistant Staphylococcus aureus: the European landscape," Journal of Antimicrobial Chemotherapy, vol. 66, no. S4, pp. iv43-iv48, 2011.

[4] Y. Taj, F. Essa, F. Aziz, and S. U. Kazmi, "Study on biofilmforming properties of clinical isolates of Staphylococcus aureus," Journal of Infection in Developing Countries, vol. 6, no. 5, pp. 403-409, 2012.

[5] A. M. Ojeda-Sana, V. Repetto, and S. Moreno, "Carnosic acid is an efflux pumps modulator by dissipation of the membrane potential in Enterococcus faecalis and Staphylococcus aureus," World Journal of Microbiology and Biotechnology, vol. 29, no. 1, pp. 137-144, 2012.

[6] M. Mombeshora and S. Mukanganyama, "Development of an accumulation assay and evaluation of the effects of efflux pump inhibitors on the retention of chlorhexidine digluconate in Pseudomonas aeruginosa and Staphylococcus aureus," BMC Research Notes, vol. 10, no. 1, p. 328, 2017.

[7] T. Hirata, R. Wakatabe, J. Nielsen, T. Satoh, S. Nihira, and A. Yamaguchi, "Screening of an inhibitor of the tetracycline efflux pump in a tetracycline-resistant clinical-isolate of Staphylococcus aureus 743," Biological \& Pharmaceutical Bulletin, vol. 21, no. 7, pp. 678-681, 1998.

[8] A. Paudel, H. Hamamoto, Y. Kobayashi, S. Yokoshima, T. Fukuyama, and K. Sekimizu, "Identification of novel deoxyribofuranosyl indole antimicrobial agents," Journal of Antibiotics, vol. 65, no. 2, pp. 53-57, 2011.

[9] J. P. Dzoyem, H. Hamamoto, B. Ngameni, B. T. Ngadjui, and K. Sekimizu, "Antimicrobial action mechanism of flavonoids from Dorstenia species," Drug Discoveries \& Therapeutics, vol. 7, no. 2, pp. 66-72, 2013.

[10] M. M. Cowan, "Plant products as antimicrobial agents," Clinical Microbiology Reviews, vol. 12, no. 4, pp. 564-582, 1999.

[11] V. Kuete, "Medicinal plant research in Africa," in Pharmacology and Chemistry, V. Kuete, Ed., Elsevier, Oxford, UK, 2013.

[12] A. G. Fankam, V. Kuete, I. K. Voukeng, J. R. Kuiate, and J. M. Pages, "Antibacterial activities of selected Cameroonian spices and their synergistic effects with antibiotics against multidrug-resistant phenotypes," BMC Complementary and Alternative Medicine, vol. 11, p. 104, 2011.

[13] J. A. Noumedem, M. Mihasan, S. T. Lacmata, M. Stefan, J. R. Kuiate, and V. Kuete, "Antibacterial activities of the methanol extracts of ten Cameroonian vegetables against Gram-negative multidrug-resistant bacteria," BMC Complementary and Alternative Medicine, vol. 13, p. 26, 2013.

[14] D. E. Djeussi, J. A. Noumedem, J. A. Seukep et al., "Antibacterial activities of selected edible plants extracts against multidrug-resistant Gram-negative bacteria," BMC Complementary and Alternative Medicine, vol. 13, no. 1, p. 164, 2013.

[15] S. B. Tankeo, P. Tane, and V. Kuete, "In vitro antibacterial and antibiotic-potentiation activities of the methanol extracts from Beilschmiedia acuta, Clausena anisata, Newbouldia laevis and Polyscias fulva against multidrug-resistant Gramnegative bacteria," BMC Complementary and Alternative Medicine, vol. 15, no. 1, p. 412, 2015.

[16] H. A. Mohammed and A. F. A. Omer, "Antibacterial activity of Azadirachta indica (Neem) leaf extract against bacterial pathogens in Sudan," American Journal of Research Communication, vol. 3, pp. 246-251, 2015.

[17] S. Maragathavalli, S. Brindha, N. S. Kaviyarasi, B. Annadurai, and S. K. Gangwar, "Antimicrobial activity in leaf extract of neem (Azadirachta indica linn.)," International Journal of Science and Nature, vol. 3, pp. 110-113, 2012.
[18] A. G. Fankam, J. R. Kuiate, and V. Kuete, "Antibacterial and antibiotic resistance modulatory activities of leaves and bark extracts of Recinodindron heudelotii (Euphorbiaceae) against multidrug-resistant Gram-negative bacteria," BMC Complementary and Alternative Medicine, vol. 17, no. 1, p. 168, 2017.

[19] H. Kim, J. Y. Moon, A. Mosaddik, and S. K. Cho, "Induction of apoptosis in human cervical carcinoma HeLa cells by polymethoxylated flavone-rich Citrus grandis Osbeck (Dangyuja) leaf extract," Food and Chemical Toxicology, vol. 48, no. 8-9, pp. 2435-2442, 2010.

[20] Z. Zarina and S. Y. Tan, "Determination of flavonoids in Citrus grandis (Pomelo) peels and their inhibition activity on lipid peroxidation in fish tissue," International Food Research Journal, vol. 20, no. 1, pp. 313-317, 2013.

[21] A. Jabamalairaj, S. Dorairaj, S. A. Yadav, and C. Bathrachalam, "Detection of functional group and antimicrobial activity of leaf extracts of Citrus grandis (L.) against selected clinical pathogens," Indo American Journal of Pharmaceutical Research, vol. 5, pp. 1642-1648, 2015.

[22] P. Saha, U. K. Mazumder, and P. K. Haldar, "Acute and subchronic toxicity of Cucurbita maxima aerial parts," International Journal of Research in Pharmaceutical and Biomedical Sciences, vol. 2, pp. 634-639, 2011.

[23] P. Saha, U. K. Mazumder, P. K. Haldar et al., "Anticancer activity of methanol extract of Cucurbita maxima against Ehrlich as-cites carcinoma," International Journal of Research in Pharmaceutical Sciences, vol. 2, no. 1, pp. 52-59, 2011.

[24] D. K. Kushawaha, S. Chatterji, M. Yadav, and G. Watal, "Antimicrobial potential and preliminary phytochemical evaluation of Cucurbita maxima seeds," International Journal of Pharma and Bio Sciences, vol. 7, pp. 578-582, 2016.

[25] C. Y. Ragasa and K. Lim, "Sterols from Cucurbita maxima," Philippine Journal of Science, vol. 134, no. 2, pp. 83-87, 2005.

[26] N. Muruganantham, S. Solomon, and M. M. Senthamilselvi, "Antimicrobial activity of Cucurbita maxima flowers (Pumpkin)," Journal of Pharmacognosy and Phytochemistry, vol. 5, no. 1, pp. 15-18, 2016.

[27] K. K. Ajibesin, E. E. Essien, and S. A. Adesanya, "Antibacterial constituents of the leaves of Dacryodes edulis," African Journal of Pharmacy and Pharmacology, vol. 5, no. 15, pp. 1782-1786, 2011.

[28] A. Bouquet, Witch Doctors and Traditional Medicine of Congo (Brazzaville), Mem Works and Documents of the Office of Scientific and Technical Research Overseas, Paris, France, 1969.

[29] P. T. Mpiana, D. S. Tshibangu, O. M. Shetonde, and K. N. Ngbolua, "In vitro antidrepanocytary actvity (anti-sickle cell anemia) of some congolese plants," Phytomedicine, vol. 14, no. 2-3, pp. 192-195, 2007.

[30] D. Daly, "Alternative medicinal course taught at the United States Medical School," Journal of Alternative and Complementary Medicine, vol. 3, no. 4, pp. 406-410, 1997.

[31] A. J. Uraku, P. M. Ajah, A. N.C. Okala, U. A. Ubiam, and P. N. Onu, "Effects of crude extract of Abelmoshus esculentus on albumin and total bilirubin of diabetic albino rats," International Journal of Science and Nature, vol. 1, no. 1, pp. 38-41, 2010.

[32] I. Dini, G. C. Tenore, and A. Dini, "Saponins in Ipomoea batatas tubers: Isolation, characterization, quantification and antioxidant properties," Food Chemistry, vol. 113, no. 2, pp. 411-419, 2009.

[33] M. Nagai, M. Tani, Y. Kishimoto et al., "Sweet potato (Ipomoea batatas L.) leaves suppressed oxidation of low density lipoprotein (LDL) in vitro and in human subjects," Journal of 
Clinical Biochemistry and Nutrition, vol. 48, no. 3, pp. 203208, 2011.

[34] S. M. Hue, A. N. Boyce, and C. Somasundram, "Antioxidant activity, phenolic and flavonoid contents in the leaves of different varieties of sweet potato (Ipomoea batatas)," Australian Journal of Crop Science, vol. 6, no. 3, pp. 375-380, 2012.

[35] H. E. Etta, C. C. Olisaeke, and C. I. Iboh, "Effect of Irvingia gabonensis (AubryLecomte ex O’Rorke) seeds on the liver and gonads of male albino rats," Journal of Biology, Agriculture and Healthcare, vol. 4, pp. 10-15, 2014.

[36] O. Nworie, J. O. Orji, U. O. Ekuma, M. V. Agah, C. S. Okoli, and M. C. Nweke, "Antibacterial activity of the leaf and stem bark of Irvingia gabonensis (Bush Mango) against Escherichia coli and Staphylococcus aureus," Global Journal of Pharmacology, vol. 10, pp. 13-18, 2016.

[37] V. Kuete, "Potential of Cameroonian plants and derived products against microbial infections: a review," Planta Medica, vol. 76, no. 14, pp. 1479-1491, 2010.

[38] V. Kuete, G. F. Wabo, B. Ngameni et al., "Antimicrobial activity of the methanolic extract, fractions and compounds from the stem bark of Irvingia gabonensis (Ixonanthaceae)," Journal of Ethnopharmacology, vol. 114, no. 1, pp. 54-60, 2007.

[39] D. Heimler, P. Vignolini, M. G. Dini, and A. Romani, "Rapid tests to assess the antioxidant activity of Phaseolus vulgaris L. dry beans," Journal of Agricultural and Food Chemistry, vol. 53, no. 8, pp. 3053-3056, 2005.

[40] D. Madhu and S. Ramica, "Antidepressant activity of aqueous extract of Phaseolus vulgaris (black bean) in rodent models of depression," International Journal of Nutrition, Pharmacology, Neurological Diseases, vol. 4, no. 2, pp. 118-124, 2014.

[41] M. Pradeepkumar, S. D. Joshi, and V. H. Kulkarni, "Evaluation of antibacterial and antitubercular activity of Phaseolus vulgaris Linn, seeds," Journal of Applied Pharmaceutical Science, vol. 5, pp. 219-224, 2015.

[42] S. T. Milan, "Total Phenolic content, flavonoid concentration and antioxidant activity of Marrubium peregrinum L. extracts," Kragujevac Journal of Science, vol. 33, pp. 63-72, 2011.

[43] V. A. Oyono, C. Fokunang, J. P. A. Assam et al., "Acute toxicity studies, antioxidant and in vitro antibacterial activities of extract from the barks of Ricinodendron heudoletti (Euphorbiaceae)," Journal of Pharmacognosy and Phytotherapy, vol. 6, no. 4, pp. 47-53, 2014.

[44] J. Momeni, R. D. Djoulde, M. T. Akam, and S. F. Kimbu, "Chemical constituents and antibacterial activities of the stem bark extracts of Ricinodendron heudelotii (Euphorbiaceae)," Indian Journal of Pharmaceutical Sciences, vol. 67, pp. 386399, 2005.

[45] C. A. Suresh-Kumar, R. Varadharajan, P. Muthumani, R. Meera, P. Devi, and B. Kameswari, "Psychopharmacological studies on the stem of Saccharum spontaneum," International Journal of PharmTech Research, vol. 2, no. 1, pp. 319-324, 2010.

[46] I. O. Williams, E. O. Onyenweaku, and I. J. Atangwho, "Nutritional and antimicrobial evaluation of Saccharum officinarum consumed in Calabar, Nigeria," African Journal of Biotechnology, vol. 15, no. 33, pp. 1789-1795, 2016.

[47] A. O. Ayoka, R. O. Akomolafe, O. S. Akinsomisoye, and O. E. Ukponmwan, "Medicinal and economic value of Spondias mombin," African Journal of Biomedical Research, vol. 11, no. 2, pp. 129-136, 2010.

[48] O. Aromolaran and O. K. Badejo, "Efficacy of fresh leaf extracts of Spondias mombin against some clinical bacterial isolates from typhoid patients," Asian Pacific Journal of Tropical Disease, vol. 4, no. 6, pp. 442-446, 2014.
[49] B. Trognitz, X. Scheldeman, K. Hansel-Hohl, A. Kuant, H. Grebe, and M. Hermann, "Genetic population structure of cacao plantings within a young production area in Nicaragua," PLoS One, vol. 6, no. 1, Article ID e16056, 2011.

[50] R. X. Santos, D. A. Oliveira, G. A. Sodre, G. Gosmann, M. Brendel, and C. Pungartnik, "Antimicrobial activity of fermented Theobroma cacao pod husk extract," Genetics and Molecular Research, vol. 13, no. 3, pp. 7725-7735, 2014.

[51] S. Nidhi, D. Shreyan, D. Abhirup, R. C. Akash, and A. Jayanthi, "Antimicrobial activity and cytotoxicity of Theobroma cacao extracts," Der Pharmacia Lettre, vol. 7, no. 7, pp. 287-294, 2015.

[52] E. J. Ndebia, B. N. Nkeh-Chungag, J. R. Temdie, Y. M. Fodjo, D. T. Ndinteh, and J. T. Mbafor, "Antinociceptive effects of the methanolic extract of Uapaca guineensis (Euphorbiaceae) stilt root bark," Pharmacologyonline, vol. 3, pp. 153-165, 2007.

[53] E. T. Ibibia, O. Peter, and O. S. Olugbemiga, "Evaluation of some Nigerian Savannah plants of antioxydent activity, and total phenols and flavonoid contents," International Journal of Pharmaceutical Sciences Review and Research, vol. 34, pp. 75-81, 2015.

[54] T. J. O. Ngalani, Influence de la Multi-Résistance des Bactéries Entériques aux Antibiotiques Sur l'État Immunologique des Patients Séropositifs au VIH Venus en Consultation à l'Hôpital Adlucem Banka de Bafang, Department of Biochemistry, University of Dschang, Dschang, Cameroon, 2015.

[55] J. Harbone, Phytochemical Methods: a Guide to Modern Techniques of Plant Analysis, Chapman \& Hall, London, UK, 1973.

[56] J. N. Eloff, “A sensitive and quick microplate method to determine the minimal inhibitory concentration of plant extracts for bacteria," Planta Medica, vol. 64, no. 8, pp. 711$713,1998$.

[57] V. Kuete, F. Nana, B. Ngameni, A. T. Mbaveng, F. Keumedjio, and B. T. Ngadjui, "Antimicrobial activity of the crude extract, fractions and compounds from stem bark of Ficus ovata (Moraceae)," Journal of Ethnopharmacology, vol. 124, no. 3, pp. 556-561, 2009.

[58] V. Kuete, J. D. Wansi, A. T. Mbaveng et al., "Antimicrobial activity of the methanolic extract and compounds from Teclea afzelii (Rutaceae)," South African Journal of Botany, vol. 74, no. 4, pp. 572-576, 2008.

[59] J. Kovač, N. Gavari, F. Bucar, and S. Smole Možina, “Antimicrobial and resistance modulatory activity of Alpinia katsumadai seed extract, essential oil and post-distillation extract," Food Technology and Biotechnology, vol. 52, pp. 248-254, 2014.

[60] V. Kuete and T. Efferth, "Cameroonian medicinal plants: pharmacology and derived natural products," Frontiers in Pharmacology, vol. 1, p. 123, 2010.

[61] J. Bruneton, Pharmacognosie: Phytochimie, Plantes medicinales, Tec \& Doc, Paris, France, 1999.

[62] M. Simões, R. N. Bennett, and E. A. Rosa, "Understanding antimicrobial activities of phytochemicals against multidrug resistant bacteria and biofilms," Natural Product Reports, vol. 26, no. 6, pp. 746-757, 2009.

[63] J. D. D. Tamokou, A. T. Mbaveng, and V. Kuete, "Chapter 8antimicrobial activities of African medicinal spices and vegetables," in Medicinal Spices and Vegetables from Africa, pp. 207-237, Academic Press, Cambridge, MA, USA, 2017.

[64] T. J. Foster, "Antibiotic resistance in Staphylococcus aureus. Current status and future prospects," FEMS Microbiology Reviews, vol. 41, no. 3, pp. 430-449, 2017. 
[65] M. C. Jennings, M. E. Forman, S. M. Duggan, K. P. C. Minbiole, and W. M. Wuest, "Efflux pumps might not be the major drivers of QAC resistance in methicillin-resistant Staphylococcus aureus," ChemBioChem, vol. 18, no. 16, pp. 1573-1577, 2017.

[66] P. W. Limaverde, F. F. Campina, F. A. da Cunha et al., "Inhibition of the TetK efflux-pump by the essential oil of Chenopodium ambrosioides L. and a-terpinene against Staphylococcus aureus IS-58," Food and Chemical Toxicology, vol. 109, pp. 957-961, 2017.

[67] M. M. Kristiansen, C. Leandro, D. Ordway et al., “Thioridazine reduces resistance of methicillin-resistant Staphylococcus aureus by inhibiting a reserpine-sensitive efflux pump," In Vivo, vol. 20, no. 3, pp. 361-366, 2006.

[68] A. Martins, L. Machado, S. Costa et al., "Role of calcium in the efflux system of Escherichia coli," International Journal of Antimicrobial Agents, vol. 37, no. 5, pp. 410-414, 2011.

[69] F. K. Touani, A. J. Seukep, D. E. Djeussi et al., "Antibioticpotentiation activities of four Cameroonian dietary plants against multidrug-resistant Gram-negative bacteria expressing efflux pumps," BMC Complementary and Alternative Medicine, vol. 14, p. 258, 2014.

[70] L. C. Braga, A. A. Leite, K. G. Xavier et al., "Synergic interaction between pomegranate extract and antibiotics against Staphylococcus aureus," Canadian Journal of Microbiology, vol. 51, no. 7, pp. 541-547, 2005. 


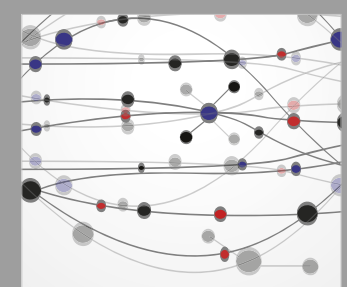

The Scientific World Journal
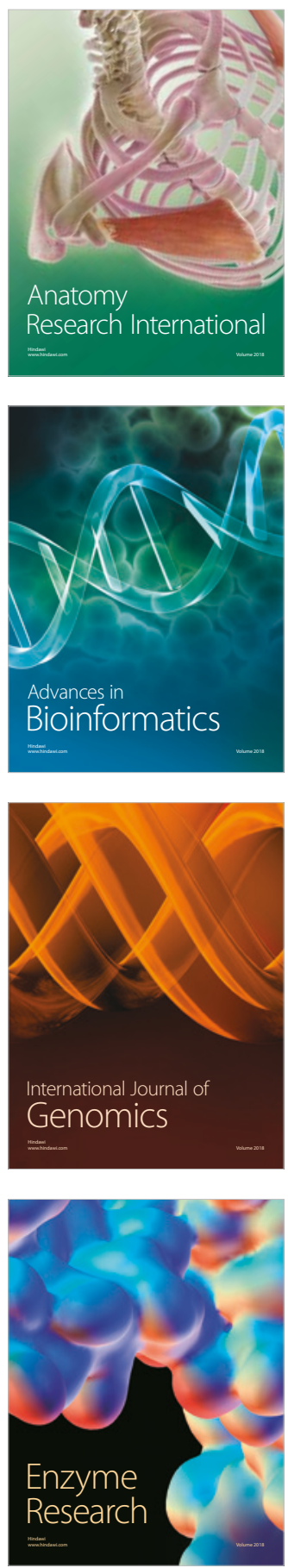
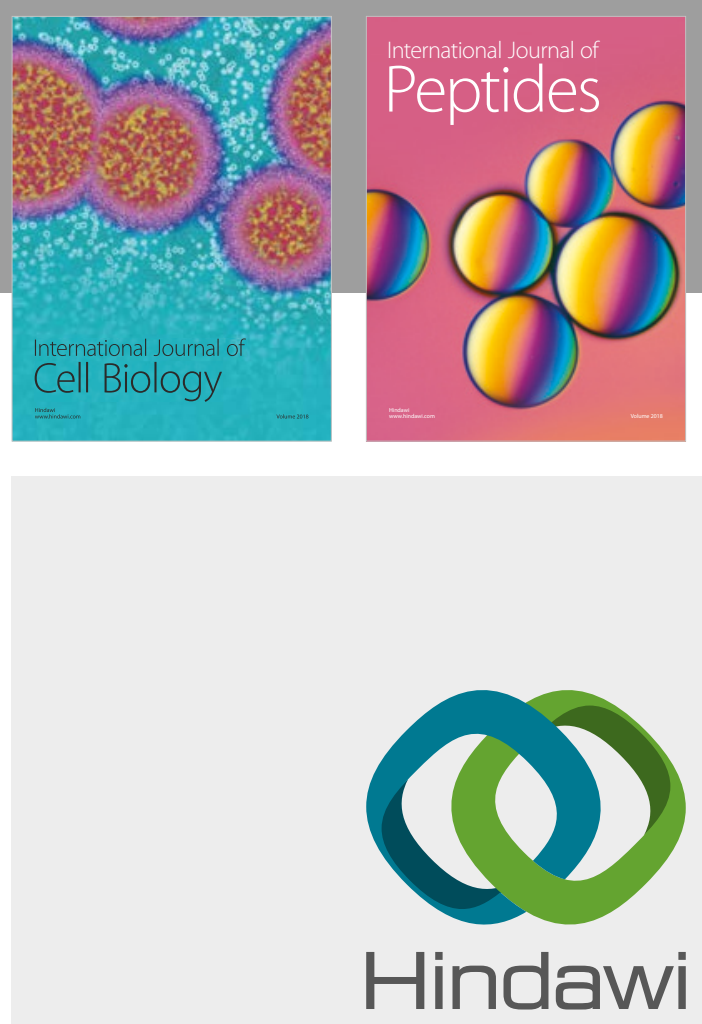

Submit your manuscripts at

www.hindawi.com
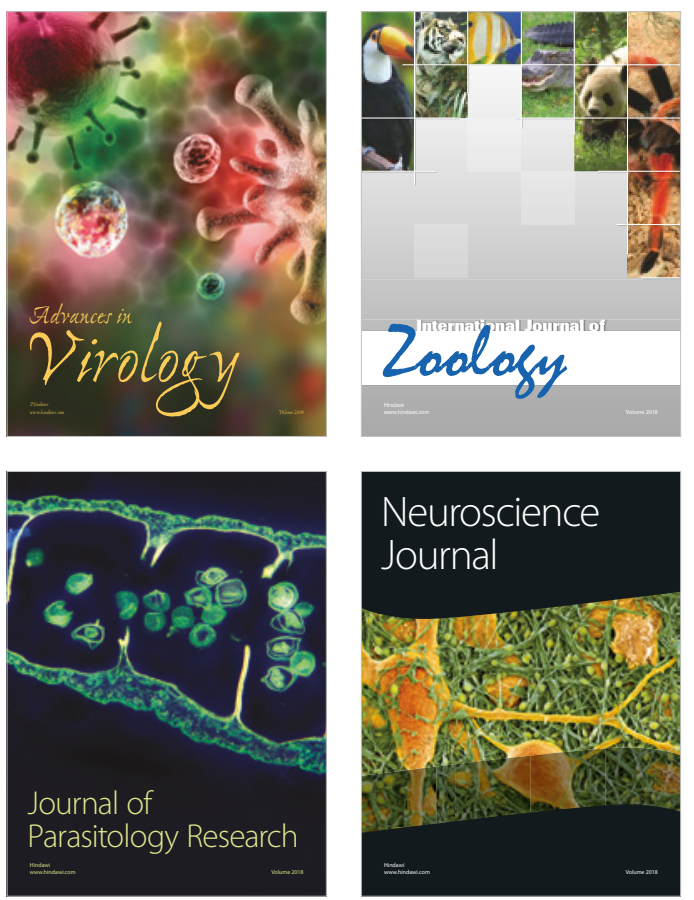
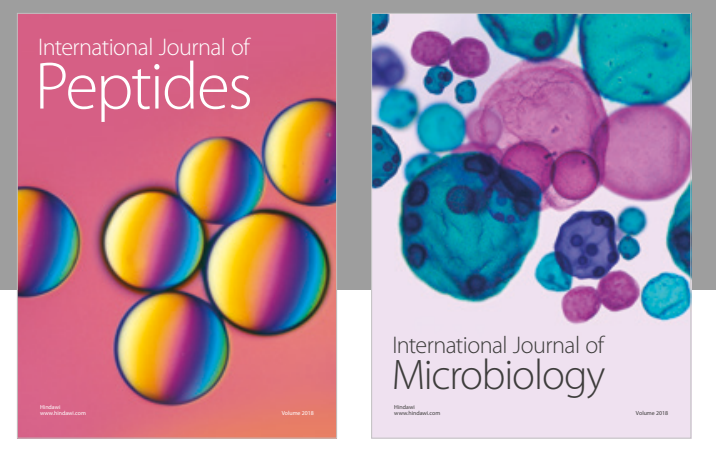

nternational Journal of Microbiology
Journal of
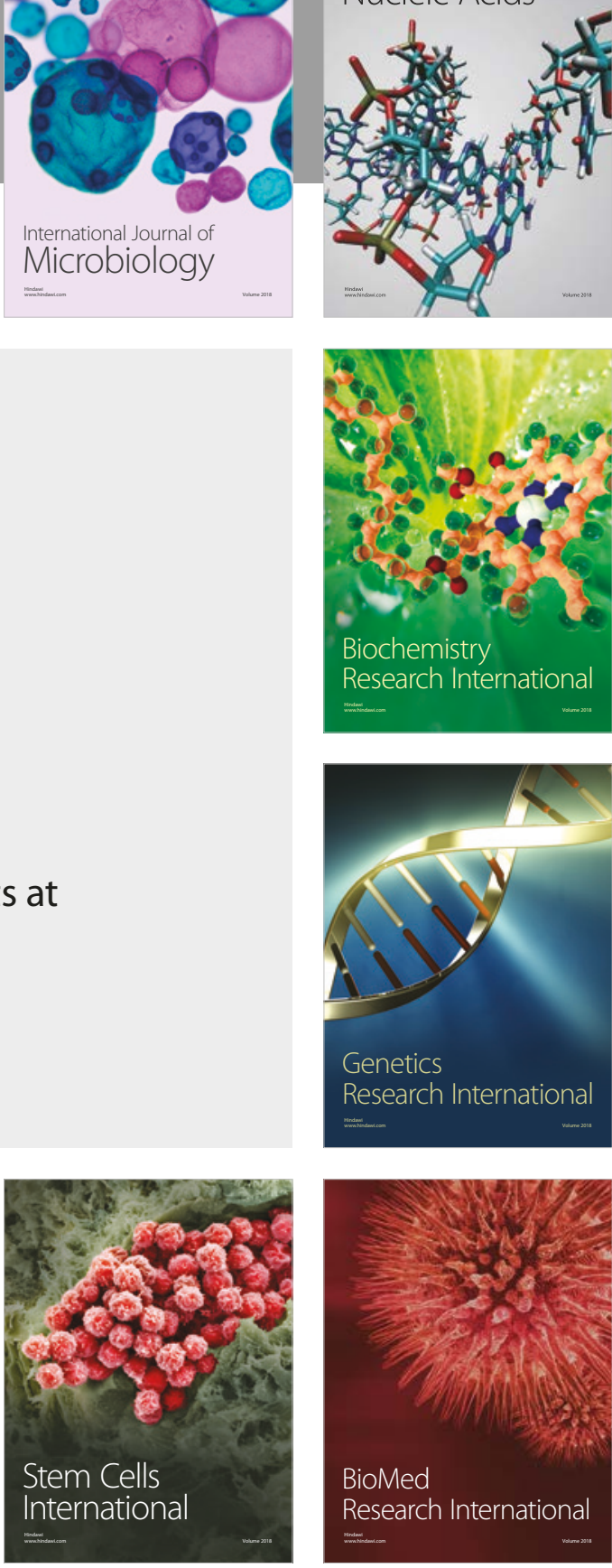
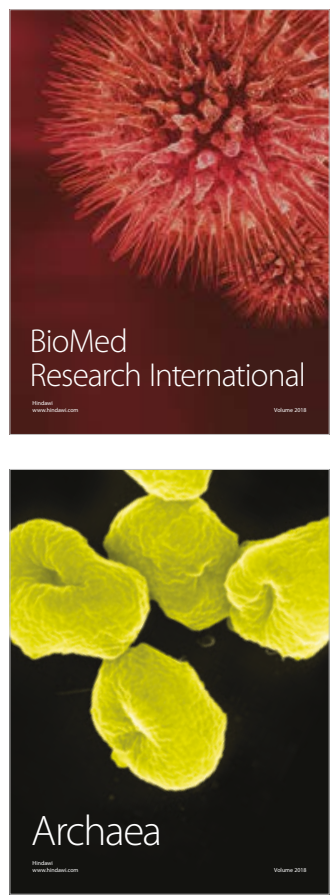